\begin{tabular}{|c|c|c|c|c|c|}
\hline Station. & $\begin{array}{c}\text { Latitude } \\
\text { N. }\end{array}$ & $\begin{array}{l}\text { Longitude } \\
\text { W. of } \\
\text { Green- } \\
\text { wich. }\end{array}$ & $\begin{array}{l}g_{1}, \\
\text { reduced to } \\
\text { sea level. }\end{array}$ & $\begin{array}{l}g_{0}, \\
\text { theoretical } \\
\text { value. }\end{array}$ & $g_{1}-g_{0}$ \\
\hline $\begin{array}{l}\text { Washington } \\
\text { Sydney (Cap }\end{array}$ & we $3^{8} 53$ & $77 \stackrel{1}{1}$ & $\begin{array}{c}\mathrm{cm} . \\
980^{\circ} \text { IOI }\end{array}$ & $\begin{array}{c}\mathrm{cm} . \\
90^{\circ} \circ 0^{\circ} 7\end{array}$ & $\begin{aligned} & \mathrm{cm} . \\
+ & 0 \% 14\end{aligned}$ \\
\hline $\begin{array}{l}\quad \text { Breton) } \\
\text { Ashe Inlet } \\
\text { Umanak } \\
\text { Niantilik }\end{array}$ & $\begin{array}{rrr}\ldots & 46 & 9 \\
\ldots & 62 & 33 \\
\ldots & 70 & 40 \\
\ldots & 64 & 53\end{array}$ & $\begin{array}{lr}60 & 12 \\
70 & 35 \\
52 & 8 \\
66 & 20\end{array}$ & $\begin{array}{l}980^{\circ} 722 \\
982^{*} 109 \\
982^{*} 594 \\
982^{*} 275\end{array}$ & $\begin{array}{l}980^{\circ} 73^{2} \\
982 \cdot 104 \\
982 \cdot 632 \\
982 \cdot 271\end{array}$ & $\begin{array}{l}-0.010 \\
+0.005 \\
-0.038 \\
+0.004\end{array}$ \\
\hline
\end{tabular}

The theoretical value is that given by the assumed formula,

$$
g_{\theta}=978.066 \text { ( } 1+0.005243 \sin ^{2} \text { latitude), }
$$

and $g_{1}$ is obtained by using Bouguer's formula.

It would not be easy to over-estimate the value of these accurate determinations of gravity, for they help to fill a very serious gap in the series of observations which have been made in various parts of the world. Prof. Helmert's recent report to the International Geodetic Association has shown that no pendulum observations had been obtained in the region visited by Mr. Putnam, and it is in the polar regions that data as to the variations of gravity are of the greatest importance and, therefore, most urgently required. Mr. Putnam concludes his report with some historical notes on the development of apparatus and the progress of research, which are very interesting. It is hardly correct, however, to say that the law $t=\pi \sqrt{\frac{l}{g}}$ applies even to the ideal simple pendulum (p. I Io). These notes contain a good account of the controversy which has arisen about the appropriateness of the second term in Bouguer's formula for the reduction of $g$ to sea level : $d g=\frac{2 g \mathrm{H}}{r}\left(\mathrm{I}-\frac{3 \delta}{4 \Delta}\right)$, where $\delta$ is density of matter lying above sea level, and $\Delta$ is the mean density of the earth. The value of pendulum observations as affording indications of surface density is insisted upon, and a practical application of the method is suggested. It is to be hoped that Mr. Putnam will see his project realised, by which the relative proportions of ice and rock in the great Greenland elevation may be determined by pendulum experiments.

\section{RAINFALL OF THE UNITED STATES}

UNER this title the Weather Bureau of the Department of Agriculture has published a bulletin containing a discussion of the observations obtained from the longest and most trustworthy rainfall registers in the United States, accompanied by annual, seasonal, and other charts. In addition to the usual tables of the mean monthly and annual precipitation, arranged according to geographical distribution, an important cleparture has been made by separately discussing the rainfall of the crop-growing season ; for, as the author remarks, however valuable a knowledge of the water supply throughout the year may be, information as to the amount of rainfall available for agricultural purposes is possibly of greater consequence.

Another departure from the ordinary treatment of the subject is the discussion of the monthly distribution by districts and types according to natural boundaries. The conditions favourable for rainfall are chiefly (I) nearness to the ocean, (2) proximity to the track of storms, and (3) the position of mountain ranges. The rainfall of the North Pacific coast is quoted as an example of the combined effect of all three conditions, the distinguishing characteristic of this type being a wet season from October to March, and a practically rainless summer, except in Northern California and parts of Oregon and Washington. About half of the yearly fall occurs between December and February. The rainfall is discussed under twelve such types; we are unable to refer specially to each of these, but the chart of mean annual precipitation shows NO. [ 476 , vOL. 57$]$ that there is a narrow belt on the north-west coast, extending from Cape Flattery on the north to midway of the Oregon coast on the south, and some distance inland, where the annual amount exceeds 50 and at some points Ioo inches. Eastward and southward the annual fall diminishes, reaching a minimum on the lowlands and valleys between the Coast Range on the west and the Sierra Nevada and the Cascade Ranges on the east, where the amount in some cases does not exceed ro inches, but in years of plentiful rainfall as much as 20 inches may fall in the best-watered parts. At Terrace (Utah), a station on the Central Pacific Railroad, the mean annual fall is only 4.3 inches, and in the driest year was as low as 0.7 inch. To the eastward of the Rocky Mountains the annual fall is from Io to 18 inches, and increases slowly to 60 inches on the Florida and Gulf coasts, and from 40 to 50 inches in the Eastern States. There is, however, a gradual clecline both from the Atlantic coast westward and from the Gulf coast northward. In considering the various rainfall values in this discussion allowance must he made for the position of the gauges which are generally exposed on roofs, owing to the stations being mostly in towns. It is well known that the amount caught in the gauge decreases with altitude above the ground, and it is estimated that the loss from this cause in the values quoted by the Weather Bureau is from 5 to Io per cent. of the total annual fall. With regard to the important subject of excessive rainfall, down to the year I 888 only one self-recording gauge was in use at the Signal Service stations; five others were added in 1889 , and the publication in the Monthly Weather Review of the maximum falls in five and ten minutes, and also in one hour, were begun. In August I 890 a cloud-burst passed over Palmetto (Nevada), when a gauge that was not exposed to the full intensity of the storm caught 8.8 inches of water in an hour, and in August $189 \mathrm{I}, 1 \mathrm{I} \frac{1}{2}$ inches were measured within an hour at Campo (California). The great majority of excessive rains are said to occur east of longitude $105^{\circ} \mathrm{W}$., and principally in the summer months, in connection with afternoon thunderstorms; they occasionally take place in the track of West India hurricanes, and are more abundant on the Gulf and South Atlantic coasts than at inland places. The maximum rates of rainfall per hour, estimated from periods of five minutes, at the Weather Bureau Stations which possess self-registering gauges, were 9 inches at Bismarck (N. Dakota); 8.4 inches at St. Paul (Wisconsin), and 8.2 inches at New Orleans.

This valuable memoir has been prepared by $\mathrm{Mr}$. A. J. Henry, under the direction of Prof. Willis L. Moore, the Chief of the Weather Bureau.

\section{NOTES.}

The German Emperor, as King of Prussia, has conferred upon Dr. John Murray, Director of the Scottish Marine Station, and formerly of the Challenger expedition, the rare distinction of knighthood in the Order Pour le Mírite founded by Frederick the Great. This is generally allowed to be the highest honour which a man of science can receive, and is limited to thirty German and twenty-five foreign knights. Lord Kelvin, Lord Lister, and Sir G. G. Stokes are the only other British men of science now alive who have received the Order. Dr. Murray has also been elected a Foreign Member of the Imperial Russian Academy of Sciences.

ThE Committee appointed by the American Society of Naturalists to inquire into the practicability and feasibility of the exploration of the Antarctic continent, report that an expenditure of from forty thousand to fifty thousand dollars would suffice for an independent scientific expedition. The Committee suggests that if this fund could not be raised by 